\title{
Analisis Risiko Teknologi Informasi Aplikasi CATTER PDAM Kota Salatiga Menggunakan ISO 31000
}

\author{
Enik Muryanti*1, Kristoko Dwi Hartomo ${ }^{2}$ \\ ${ }^{1,2}$ Universitas Kristen Satya Wacana; Jl. Diponegoro No.52-60, Salatiga, Kec. Sidorejo, Kota \\ Salatiga, Jawa Tengah 50771, (0298) 321212 \\ ${ }^{3}$ Jurusan Sistem Informasi, FTI UKSW, Salatiga \\ e-mail:*1682017033@student.uksw.edu, ${ }^{2}$ Kristoko@uksw.edu
}

\begin{abstract}
Abstrak
Catat Meter (CATTER) merupakan sistem pencatatan stand meter air pelanggan pada PDAM Kota Salatiga. Aplikasi Catat Meter membantu perusahaan dalam proses memasukan data stand meter air pelanggan pada setiap harinya dan memepermudah dalam pelaporan tagihan air warga Kota Salatiga. Penelitian dilakukan dengan menggunakan metode ISO 31000 yang merupakan sebuah framework yang digunakan sebagai pedoman penerapan manajemen analisis risiko yang memilki beberapa tahapan yaitu tahap pertama penilaian risiko (risk assessment) yang terdiri dari 3 tahapan yaitu identifikasi risiko (risk identification), analisis risiko (risk analyst), evaluasi risiko (risk evaluation). Tahapan selanjutnya adalah perlakuan risiko (risk threatment). Terdapat 4 kemungkinan risiko yang termasuk dalam tingkatan high, 13 kemungkinan yang termasuk dalam tingkatan medium, dan 9 kemungkinan risiko yang termasuk dalam tingkatan low. Permasalahan yang muncul adalah kurangnya proses maintenance pada asset yang dimiliki oleh aplikasi Catat Meter yang belum dilakukan secara optimal. Dengan menerapkan risk reduction perusahaan mampu meminimalisir kemungkinan risiko dan dampak yang ada.
\end{abstract}

Kata kunci-Catat Meter, International Organzation for Standardiation (ISO) 31000, Analisis Risiko, Risk Reduction

\begin{abstract}
Catat Meter (CATTER) is a recording system for customer water meter stands at PDAM Salatiga City. The Catat Meter application helps companies in the process of entering customer water meter stand data every day and makes it easier to report water bills for residents of the City of Salatiga. The study was conducted using the ISO 31000 method, which is a framework used as a guideline for implementing risk analysis management which has several stages, namely the first stage of risk assessment which consists of 3 stages, namely risk identification, risk analysis, risk evaluation. The next stage is risk treatment. There are 4 possible risks that are included in the high level, 13 possibilities that are included in the medium level, and 9 possible risks that are included in the low level. The problem that arises is the lack of maintenance processes on assets owned by the Catat Meter application that have not been carried out optimally. By implementing risk reduction, the company is able to minimize the possible risks and impacts
\end{abstract}

Keywords - Catat Meter, International Organzation for Standardiation (ISO) 31000, Risk Analysis, Risk Reduction 


\section{PENDAHULUAN}

PDAM Kota Salatiga merupakan BUMD yang bergerak dibidang penyediaan air minum untuk wilayah Kota Salatiga. PDAM Kota Salatiga mempunyai beberapa sistem informasi yang terintegrasi antar bagian, salah satunya untuk memasukkan data meter pelanggan terkait dengan pembayaran tagihan air. Aplikasi ini digunakan untuk mempermudah pelaporan tagihan air warga Kota Salatiga [1]. Catat meter (CATTER) merupakan sistem pencatatan stand meter air pelanggan yang berbasis website dan android yang dikoneksikan secara langsung dengan Sistem Rekening Online (RO). Data yang dimasukan dalam aplikasi CATTER berupa data input angka meter. Data tersebut akan dimasukan ke sistem RO dan secara otomatis akan diolah menjadi rekening air pelanggan yang digunakan sebagai bukti pembacaan meter pelanggan pada setiap bulannya.

Dalam penggunaan sebuah sistem tidaklah menutup kemungkinan adanya ancaman risiko yang muncul sehingga dapat mengganggu kinerja pegawai dalam melaksanakan tugasnya. Kendala yang muncul yaitu dalam proses pengiriman data melalui aplikasi CATTER tidak terbaca. Hal ini terjadi karena web service mati secara tiba-tiba. Kemudian mengalami kegagalan update software dan koneksi jaringan yang tidak stabil. Hal-hal yang termasuk dalam risiko teknologi informasi ada pada aset TI, pengembangan TI sebagai bagian dari pengendalian dari manajemen bisnis, hingga bencana yang diakibatkan oleh TI yang dapat mengakibatkan terhentinya proses bisnis [2]. Oleh sebab itu, penelitian ini dilakukan untuk menganalisis proses manajemen risiko teknologi informasi yang terdapat pada aplikasi Catat Meter dengan cara mengidentifikasi kemungkinan risiko, mengetahui dampak risiko yang mungkin terjadi, memberikan penilaian dan evaluasi terhadap risiko serta melakukkan antisipasi risiko dari permasalahan yang ada.

Tujuan utama dari manajemen risiko adalah untuk memberikan gambaran tentang kemungkinan ancaman yang dapat terjadi sehingga perusahaan dapat menyusun strategi dan langkah-langkah untuk mitigasi dan evaluasi risiko [3].Tindakan ini telah diatur dalam metode ISO 31000:2018 yaitu tentang manajemen risiko, dimana manajemen risiko adalah tindakan yang digunakan untuk mengendalikan risiko perusahaan dalam kegiatan operasional perusahaan dengan melakukan analisis risiko, evaluasi risiko, dan rencana mitigasi [4].

Berdasarkan dari beberapa penelitian sebelumnya tentang analisis risiko menggunakan ISO 31000, maka akan dilakukan penelitian tentang analisis risiko teknologi informasi aplikasi CATTER pada PDAM Kota. Penelitian tentang analisis risiko belum pernah dilakukkan oleh peneliti sebelumnya, dan dapat dilihat terdapat hubungan metode yang akan digunakan oleh penulis untuk melakukkan sebuah analisis risiko pada aplikasi CATTER yaitu dengan menggunakan ISO 31000 yang bertujuan untuk menghasilkan dokumentasi kemungkinan risiko yang muncul, melakukan penilaian dan pengevaluasian risiko beserta level dampak risiko tersebut, mengidentifikasi aset-aset teknologi informasi yang digunakan, serta memberikan rekomendasi terhadap perlakuan risiko yang dapat digunakan untuk meminimalisir kemungkinan risiko yang mungkin terjadi.

\section{METODE PENELITIAN}

\subsection{Penelitian Terdahulu}

Penelitian analisis manajemen risiko teknologi informasi pada website Ecofo menggunakan ISO 31000 pada KPH Banyu Mas Timur yang dilakukan oleh Miftakhatun pada tahun 2020. Penelitian ini menggunakan metode ISO 31000 menghasilkan 24 dokumentasi 
risiko yang ditemukan. Terdapat 3 risiko level high , 10 risiko level medium, dan 11 risiko level low yang digunakan sebagai acuan pencegahan, penanganan, dan pemeliharaan terhadap aset TI [5].

Analisis risiko teknologi informasi terhadap aplikasi iTop dengan menggunakan ISO 31000 juga pernah dilakukkan oleh Aprillia Rahmawati pada tahun 2019. Dari penelitian tersebut terdapat 21 kemungkinan risiko yang dapat menganggu kinerja dari aplikasi iTop. Dari 21 kemungkinan risiko tersebut 8 diantaranya berada di level medium serta terdapat 17 kemungkinan resiko yang berada di level low. Dari penelitian tersebut diharapkan dapat meminimalisir kemungkinan risiko di aplikasi iTop [6].

Penelitian yang berkaitan dengan ISO 31000 yang dilakukan oleh Reski Mai Candra pada tahun 2019. Analisi yang dilakukan tentang "Sistem Manajemen Risiko Keamanan Aset Teknologi Informasi Menggunakan ISO 31000:2018" ditemukan adanya 45 kemungkinan risiko yang teridentifikasi diantaranya 14 kemungkinan resiko berada di low level, 16 kemungkinan risiko berada di medium level, serta 15 kemungkinan risiko berada di high level. Diharapkan sistem manajemen risiko dapat dikembangkan dengan memberikan rekomendasi hasil dari penilaian risiko yang diperoleh [7].

\section{2 Landasan Teori}

\subsubsection{Risiko Sistem Informasi}

Risiko yang terjadi dapat melumpuhkan aktivitas di dalam sistem sehingga sistem tidak dapat berjalan secara optimal, baik risiko internal maupun risiko eksternal. Risiko internal seperti kegagalan sistem, kegagalan jaringan, kerusakan hardware dan software, kehilangan data, virus, untuk risiko eksternal terdapat gangguan alam seperti petir, banjir, hujan dan angin yang dapat merusak infrastruktur IT sehingga mengganggu kelangsungan proses bisnis [8].

\subsubsection{Manajemen Risiko}

Manajemen risiko adalah pendekatan terstruktur/metodologis untuk mengelola ketidakpastian terkait ancaman dari serangkaian aktivitas manusia yang meliputi: menilai risiko, mengembangkan strategi untuk mengelolanya, dan memitigasi risiko dengan kemungkinan pemberdayaan/pengelolaan sumber daya [9]. Tujuan dari manajemen risiko adalah untuk meminimalkan risiko dengan mengelola risiko agar diperoleh hasil yang optimal, sehingga kecil kemungkinan risiko yang ada dapat segera diperbaiki [10].

\subsubsection{ISO 31000}

ISO 31000 adalah standar penerapan manajemen risiko yang diterbitkan oleh ISO (International Organization for Standardization) pada tanggal 13 November 2009. Standar ini dimaksudkan untuk dapat diterapkan dan disesuaikan untuk semua jenis organisasi dengan memberikan struktur dan pedoman umum yang berlaku untuk operasi yang terkait dengan manajemen risiko agar perusahaan memiliki pedoman dalam upaya meminimalisir kemungkinan risiko [11]. Standart ini memliki beberapa tahapan, tahapan yang pertama adalah Penilaian Risiko (Risk Assessment). Penilaian risiko (Risk Assessment) merupakan suatu langkah untuk menentukan potensi risiko yang akan mempengarui tujuan dari organisasi. Penilaian Risiko memiliki 3 tahapan di dalamnya, yaitu Identifikasi Risiko (Risk Identification), analisis risiko (Risk Analys), dan evaluasi risiko (Risk Evaluation). Tahap kedua adalah perawatan risiko (Risk Treatment). Pada tahap ini meliputi upaya untuk menyeleksi kemungkinan dampak-dampak risiko serta mencegah dampak risiko yang mungkin terjadi [12]. 


\subsection{Metode Penelitian}

Metode penelitian yang digunakan dalam proses penilaian risiko menggunakan kerangka kerja ISO 31000. Berdasarkan International Organization for Standardization (ISO 31000) penelitian ini akan dilakukan dengan menggunakan 2 tahap yaitu pencarian informasi yang dibutuhkan yang diperoleh melalui proses wawancara dengan sumber internal PDAM Kota Salatiga dan tahapan yang kedua adalah mengelola data wawancara yang diperoleh kemudian dianalisa berdasarkan tahapan dalam framework ISO 31000 . Hasil yang didapatkan berupa data kualitatif yang dilakukan melalui wawanara dengan narasumer yang terkait pada bidang catat meter. Berikut ini adalah prinsip-prinsip kerangka kerja dan proses manajemen risiko menggunakan kerangka kerja ISO 31000.

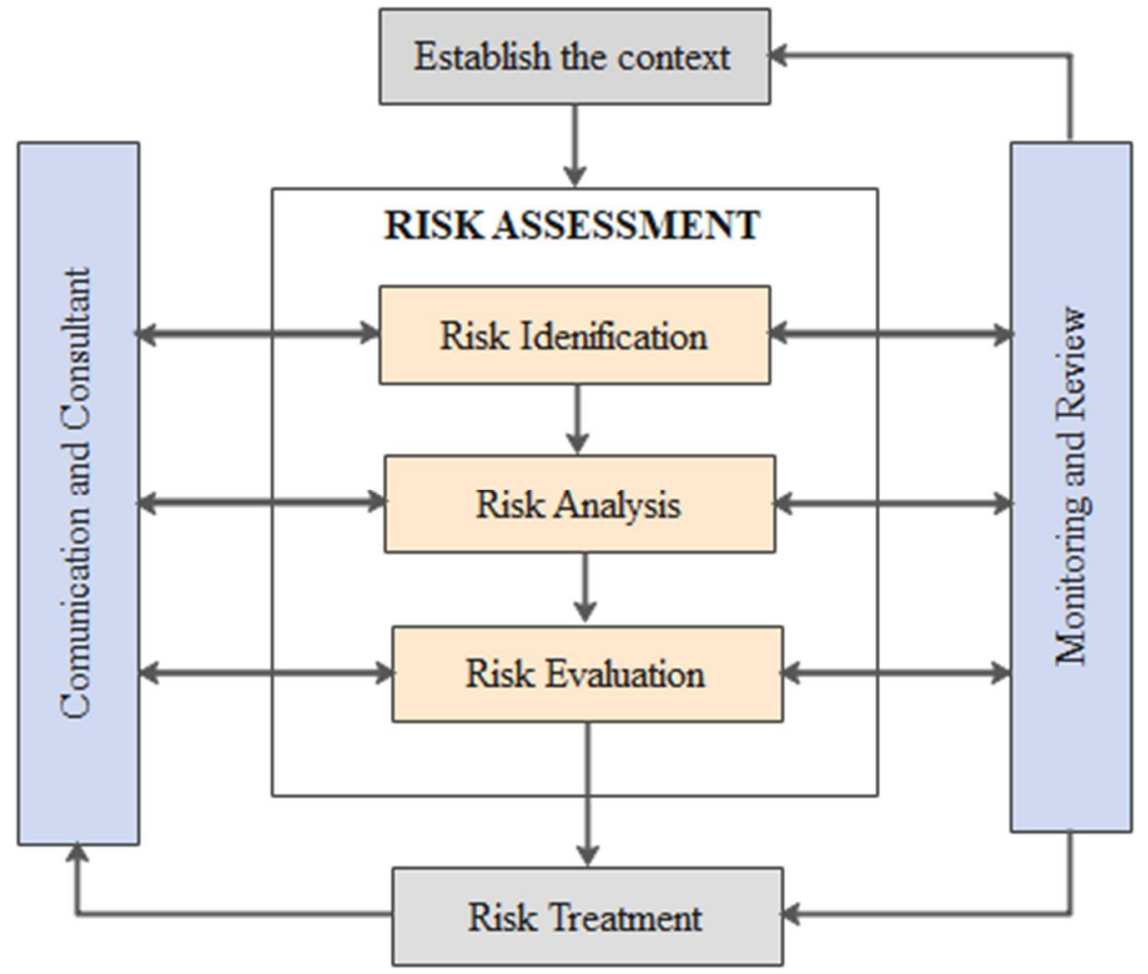

Gambar 1. Prinsip Kerangka Kerja ISO 31000

\subsubsection{Komunikasi dan Konsultasi (Communication and Consultation)}

Dalam penelitian ini, komunikasi dan konsultasi dengan pemangku kepentingan sangat penting karena mereka dapat memberikan pertimbangan dan penilaian risiko berdasarkan persepsi mereka terhadap risiko tersebut [13].

\subsubsection{Penetapan Konteks (Establishing the Context)}

Dalam menentukan konteks, ada empat konteks yang perlu ditentukan, konteks tersebut meliputi konteks internal, konteks eksternal, konteks manajemen risiko, dan kriteria risiko [13].

\subsubsection{Penilaian risiko (Risk Assesment)}

Tahapan ini dilakukan untuk mengetahui potensi risiko yang akan mempengaruhi perusahaan untuk mencapai tujuan bisnis [10]. Penilaian risiko terdiri dari 3 tahapan didalamya, diantaranya sebagai berikut: 


\subsubsection{Identifikasi Resiko (Risk Identification)}

Identifikasi risiko yang dilakukan dengan proses wawancara terhadap pihak internal perusahaan secara mendalam.

\subsubsection{Analisis Resiko (Risk Analys)}

Penilaian Resiko merupakan proses untuk menentukan potensi resiko yang mampu menghambat tujuan bisnis perusahaan.

\subsubsection{Evaluasi Resiko (Risk Evaluation)}

Evaluasi resiko merupakan sebuah proses evaluasi atau penilaian terhadap kemungkinan risiko berdasarkan tingkat risiko yang telah ditentukan.

\subsubsection{Perlakuan risiko (Risk Threatment)}

Tahapan ini dilakukan dengan upaya melengkapi pilihan yang tepat dan dapat mengurangi atau bahkan menghilangkan kemungkinan dan dampak dari risiko yang terjadi pada perusahaan serta menerapkan perlakuan terhadap risiko yang ada [11].

\section{HASIL DAN PEMBAHASAN}

Setelah melakukan wawancara dan mendapatkan data yang telah dibutukan, maka langkah selanjutnya adalah melakukan penilaian risiko yang bertujuan untuk menganalisis risiko pada aplikasi CATTER dengan menggunakan ISO 31000. Masalah yang sering terjadi pada aplikasi CATTER yaitu muncul dari beberapa faktor diantaranya yaitu faktor alam, faktor manusia, serta faktor sistem dan infrastruktur yang memungkinkan terjadinya dampak risiko terhadap aplikasi CATTER pada PDAM Kota Salatiga.

\subsection{Penilaian risiko (Risk Assesment)}

Tahap penilaian risiko terdiri dari 3 tahap yaitu tahap identifikasi risiko, tahap analisis risiko, dan tahap evaluasi risiko.

\subsubsection{Tahap Identifikasi Risiko}

\subsubsection{Identifikasi Aset CATTER}

Tahap identifikasi risiko dilakukan dengan proses wawancara dan observasi kepada pegawai bagian catat meter yang mengakses aplikasi CATTER. Pada tahap ini aset-aset yang terkait dengan aplikasi CATTER akan di identifikasi berdasarkan software dan hardware yang digunakan pada aplikasi CATTER dapat dilihat sebagai berikut:

Tabel 1. Identifikasi Aset Catat Meter

\begin{tabular}{|c|c|}
\hline Komponen Sistem Informasi & Aset Catat Meter (CATTER) \\
\hline \multirow{4}{*}{ Data } & 1. Data Pelanggan \\
\hline & 2. Data Foto Meter \\
\hline & 3. Data Input Angka Meter \\
\hline & 4. Data Petugas \\
\hline Software & 1. Sistem Operasi Berasis Andro \\
\hline
\end{tabular}

Enik, et., al [Analisis Risiko Teknologi Informasi Aplikasi CATTER PDAM Kota Salatiga Menggunakan ISO 31000] 


\begin{tabular}{|l|ll|} 
& 2. & PostgreSQL \\
\hline \multirow{4}{*}{ Hardware } & 1. & Personal Computer $(\mathrm{PC})$ \\
\cline { 2 - 3 } & 2. & Server Database \\
\cline { 2 - 3 } & 3. & Smartphone \\
\hline
\end{tabular}

\subsubsection{Identifikasi Kemungkinan Risiko dan Dampak Risiko}

Tahap identifikasi kemungkinan risiko telah ditemukan 26 kemungkinan risiko yang berpotensi mengganggu dalam penerapan aplikasi CATTER. Maka langkah selanjutnya yaitu melakukan identifikasi terhadap dampak risiko yang mungkin terjadi pada aplikasi CATTER. Dampak risiko yang muncul diakibatkan oleh beberapa faktor diantaranya faktor alam, manusia, system dan infrastruktur. Sehingga dalam tahap ini dampak risiko yang muncul akan dapat teridentifikasi. Berikut adalah uraian dari identifikasi dampak risiko.

Tabel 2. Identifikasi Kemungkinan Risiko dan Dampak Risiko

\begin{tabular}{|c|l|l|}
\hline Id & Kemungkinan Risiko & \multicolumn{1}{|c|}{ Dampak } \\
\hline R01 & Banjir & $\begin{array}{l}\text { Terjadi kerusakan infrastruktur dan menghambat aktivitas } \\
\text { bisnis perusahaan. }\end{array}$ \\
\hline R02 & Gempa Bumi & $\begin{array}{l}\text { Terjadi kerusakan insfrastruktur dan proses bisnis } \\
\text { perusahaan terhenti. }\end{array}$ \\
\hline R03 & Petir & $\begin{array}{l}\text { Mengalami kerusakan infrastrutur pada perusahaan dan } \\
\text { mengalami kerugian secara finansial. }\end{array}$ \\
\hline R04 & Kebakaran & $\begin{array}{l}\text { Terjadi kerusakan infrastruktur perusahaan, proses bisnis } \\
\text { terhenti, perusahaan mengalami kerugian secara finansial. }\end{array}$ \\
\hline R05 & Listrik Padam & Seluruh akifitas pada perusahaan terhenti. \\
\hline R06 & Human Error & $\begin{array}{l}\text { Sistem operasi tidak berjalan secara optimal, proses bisnis } \\
\text { terhenti. }\end{array}$ \\
\hline R07 & $\begin{array}{l}\text { Data dan Informasi } \\
\text { tidak sesuai }\end{array}$ & $\begin{array}{l}\text { Dalam pengiriman data yang dilaporkan data tidak valid. } \\
\text { R08 }\end{array}$ Penyalahgunaan hak \\
akses & $\begin{array}{l}\text { Mengakibatkan kebocoran informasi data dan } \\
\text { memungkinkan manipulasi data. }\end{array}$ \\
\hline R09 & Kurangnya SDM & Mengakibatkan kesulitan dalam proses pembagian kerja. \\
\hline R10 & $\begin{array}{l}\text { Cybercrime } \\
\text { Vandalisme }\end{array}$ & $\begin{array}{l}\text { Adanya manipulasi data serta pencurian data baik yang } \\
\text { terlihat maupun yang tidak terlihat. }\end{array}$ \\
\hline R11 & Server down & $\begin{array}{l}\text { Kegagalan dalam melakukan hak akses ke aplikasi } \\
\text { CATTER dan database utama. }\end{array}$ \\
\hline R12 & Backup Failure & $\begin{array}{l}\text { Data laporan yang akan diterima oleh rekening online } \\
\text { RO) tidak lengkap. }\end{array}$ \\
\hline R13 & Overhead & $\begin{array}{l}\text { Kinerja hardware kurang maksimal, karena rusaknya } \\
\text { hardware yang harus menanggung suhu panas yang terus } \\
\text { menerus. }\end{array}$ \\
\hline R14 & Data Corrupt & $\begin{array}{l}\text { Mengalami kerusakan data, aplikasi CATTER tidak dapat } \\
\text { menerima data yang valid. }\end{array}$ \\
\hline R15 & Overcapacity & $\begin{array}{l}\text { Inputan data baru yang berkaitan dengan hasil penginputan } \\
\text { data pelanggan gagal ditampung oleh database utama. }\end{array}$ \\
\hline R16 & Overload & $\begin{array}{l}\text { Kehilangan data dan proses loading terhambat karena log } \\
\text { database dan log temp database terisi penuh. }\end{array}$ \\
\hline
\end{tabular}

Enik, et., al [Analisis Risiko Teknologi Informasi Aplikasi CATTER PDAM Kota Salatiga Menggunakan ISO 31000] 


\begin{tabular}{|l|l|l|l|} 
R17 & $\begin{array}{l}\text { Web service mati } \\
\text { secara tiba-tiba }\end{array}$ & $\begin{array}{l}\text { Pegawai catat meter tidak dapat mengkases aplikasi } \\
\text { CATTER dan pengiriman data tidak masuk ke dalam } \\
\text { laporan rekening online (RO). }\end{array}$ \\
\hline R18 & $\begin{array}{l}\text { Koneksi jaringan } \\
\text { terputus }\end{array}$ & Kegagalan dalam melakukan akses ke aplikasi CATTER. \\
\hline R19 & $\begin{array}{l}\text { Koneksi jaringan } \\
\text { tidak stabil }\end{array}$ & $\begin{array}{l}\text { Kegagalan dalam proses pengiriman data catat meter ke } \\
\text { aplikasi rekening online (RO). }\end{array}$ \\
\hline R20 & $\begin{array}{l}\text { Penyelasaian data } \\
\text { tidak tepat waktu }\end{array}$ & $\begin{array}{l}\text { Proses dalam memasukan data CATTER tidak tepat } \\
\text { waktu. }\end{array}$ \\
\hline R21 & $\begin{array}{l}\text { Dokumentasi data } \\
\text { tidak lengkap }\end{array}$ & $\begin{array}{l}\text { Dokumen-dokumen yang dibutuhkan dalam CATTER } \\
\text { tidak lengkap. }\end{array}$ \\
\hline R22 & Memori penuh & Data tidak bisa tersimpan dalam komputer. \\
\hline R23 & Kegagalan software & Software tidak bisa berjalan. \\
\hline R24 & Kegagalan hardware & $\begin{array}{l}\text { Hardware mengalami kerusakan dan tidak bisa di } \\
\text { fungsikan. }\end{array}$ \\
\hline R25 & Serangan virus & $\begin{array}{l}\text { Mengalami kehilangan data sehingga proses bisnis } \\
\text { terganggu. }\end{array}$ \\
\hline R26 & $\begin{array}{l}\text { Proses maintenance } \\
\text { tidak terjadwal }\end{array}$ & Menganggu proses bisnis pada aplikasi CATTER. \\
\hline
\end{tabular}

\subsubsection{Analisis Risiko}

Analisis risiko adalah proses yang digunakan untuk menilai kemungkinan risiko yang telah diidentifikasi oleh proses sebelumnya. Proses penilaian risiko menggunakan tabel kriteria kemungkinan yang dibagi menjadi 5 kriteria dengan menentukan berapa banyak kemungkinan risiko yang terjadi dalam waktu tertentu. Kriteria pertama adalah Langka (Rare), Kemungkinan Jarang Terjadi (Unlikely), Kemungkinan Kadang Terjadi (Possible), Kemungkinan Besar Terjadi (Likely), dan Kemungkinan Hampir Selalu Terjadi (Major). Risiko dikategorikan rendah atau tinggi tergantung dampak yang ditimbulkan dari risiko tersebut.

Tabel 3. Nilai pada Likelihood

\begin{tabular}{|c|c|c|c|}
\hline \multicolumn{2}{|c|}{ Likelihood } & \multirow{2}{*}{ Deskripsi } & \multirow{2}{*}{$\begin{array}{l}\text { Frekuensi } \\
\text { Kejadian }\end{array}$} \\
\hline Nilai & Kriteria & & \\
\hline 1 & Rare & $\begin{array}{l}\text { Risiko tersebut hampir tidak pernah } \\
\text { terjadi }\end{array}$ & $>2$ tahun \\
\hline 2 & Unlikely & Risiko tersebut jarang terjadi & $1-2$ tahun \\
\hline 3 & Possible & Risiko tersebut kadang terjadi & $7-12$ bulan \\
\hline 4 & Likely & $\begin{array}{l}\text { Risiko tersebut kemungkinan besar } \\
\text { terjadi (sering) }\end{array}$ & $4-6$ bulan \\
\hline 5 & Certain & Risiko tersebut hampir selalu terjadi & $1-6$ bulan \\
\hline
\end{tabular}

Setelah menemukan nilai kemungkinan (likelihood) pada Tabel 3 selanjutnya akan dilakukan proses untuk menentukan penilaian dampak (impact) pada perusahaan terhadap kemungkinan risiko yang terjadi. Terdapat 5 kriteria impact didalamnya, yaitu Insigificant, Minor, Moderate, Major dan Catastrophic. Insignificant merupakan dalam nilai kriteria dampak yang paling rendah sehingga tidak berpengaruh bagi instansi, sedangkan Catastrophic merupakan nilai kriteria dampak paling tinggi yang sangat berpengaruh bagi perusahaan. Berikut merupakan tabel nilai dari impact. 
Tabel 4. Nilai pada Impact

\begin{tabular}{|c|l|l|}
\hline \multicolumn{2}{|c|}{ Impact } & \multicolumn{2}{|c|}{ Deskripsi } \\
\hline Nilai & \multicolumn{1}{|c|}{ Kriteria } & \multicolumn{1}{|c|}{} \\
\hline 1 & Insignificant & $\begin{array}{l}\text { Risiko tidak menganggu kegiatan dan proses bisnis pada } \\
\text { instansi. }\end{array}$ \\
\hline 2 & Minor & $\begin{array}{l}\text { Aktivitas pada instansi sedikit terhambat, namun tidak } \\
\text { menganggu aktivitas inti pada instansi. }\end{array}$ \\
\hline 3 & Moderate & $\begin{array}{l}\text { Risiko tersebut menganggu jalannya proses bisnis pada instansi, } \\
\text { sehingga sebagian jalannya aktivitas terhambat. }\end{array}$ \\
\hline 4 & Major & $\begin{array}{l}\text { Risiko tersebut menghambat hampir seluruh jalannya proses } \\
\text { bisnis pada instansi. }\end{array}$ \\
\hline 5 & Catastrophic & $\begin{array}{l}\text { Risiko mengganggu jalannya proses bisnis yang ada secara } \\
\text { menyeluruh dan menghentikan aktivitas instansi secara total. }\end{array}$ \\
\hline
\end{tabular}

Kemudian penilaian risiko terhadap aplikasi Catat Meter (CATTER) dapat dilihat pada tabel penilaian kemungkinan risiko dan dampak yang akan mempengaruhi dari risiko tersebut. Setelah melakukan penilaian terhadap kemungkinan risiko maka akan diidentifikasi berdasarkan dengan tingkat risiko yang telah dikategorikan.

\subsubsection{Evaluasi Resiko (Risk Evaluation)}

Tahapan terakhir yaitu evaluasi risiko, proses yang dilakukan yaitu mengidentifikasi dan menganalisis kemungkinan risiko yang tela di identifikasi sebelumnya. Hasil analisis tersebut kemudian dimasukkan kedalam matrix evaluasi risiko, matrix evaluasi tersebut dikategorikan menjadi 3 level risiko yaitu Low, Medium, dan High. Level Low dikategorikan sebagai tingkatan risiko yang paling rendah, level medium dikategorikan sebagai tingkatan resiko menengah, dan level high dikategorikan sebagai tingkatan risiko yang paling tinggi. Berikut merupakan matrix evaluasi risiko:

Tabel 5. Matrix Evaluasi Risiko

\begin{tabular}{|c|c|c|c|c|c|c|c|}
\hline \multirow{7}{*}{$\begin{array}{l}\widetilde{Z} \\
0 \\
\frac{0}{\tilde{a}} \\
\frac{\pi}{3}\end{array}$} & Certain & 5 & \multirow{2}{*}{ Medium } & Medium & High & High & High \\
\hline & Likely & 4 & & Medium & Medium & High & High \\
\hline & Possible & 3 & Low & Medium & Medium & Medium & High \\
\hline & Unlikely & 2 & Low & Low & Medium & Medium & Medium \\
\hline & Rare & 1 & Low & Low & Low & Medium & Medium \\
\hline & Impact & & 1 & 2 & 3 & 4 & 5 \\
\hline & & & Insigficant & Minor & Moderate & Major & Catastrophic \\
\hline
\end{tabular}

Dari 26 kemungkinan risiko yang telah dikelompokan berdasarkan Likelihood dan Impact didalamnya terdapat kesesuaian rasio yang sesuai dengan matrix evaluasi risiko. Kemudian dari 26 kemungkinan risiko tersebut akan dikategorikan kedalam penilaian likelihood dan impact yang akan disesuaikan dengan tingkatan risiko yaitu tingkatan level risiko high, medium dan low. Hasil pengelempokan penilaian tersebut dapat dilihat pada tabel 8 yaitu pengelompokan risiko berdasarkan tingkatan risiko. 
Tabel 6. Pengelompokan Risiko Berdasarkan Tingkatan

\begin{tabular}{|c|l|c|c|l|}
\hline Id & \multicolumn{1}{|c|}{ Kemungkinan Risiko } & Likelihood & Impact & Risk Level \\
\hline R07 & Data dan Informasi tidak sesuai & 4 & 4 & High \\
\hline R17 & Web service mati secara tiba-tiba & 4 & 4 & High \\
\cline { 2 - 4 } R18 & Koneksi jaringan terputus & 4 & 4 & High \\
\hline R21 & Dokumentasi data tidak lengkap & 4 & 4 & High \\
\hline R06 & Human Error & 4 & 3 & Medium \\
\hline R14 & Data Corrupt & 4 & 3 & Medium \\
\hline R05 & Listrik Padam & 3 & 3 & Medium \\
\hline R19 & Koneksi jaringan tidak stabil & 3 & 3 & Medium \\
\hline R23 & Kegagalan software & 3 & 3 & Medium \\
\hline R03 & Petir & 2 & 3 & Medium \\
\hline R20 & Penyelesaian data tidak tepat waktu & 2 & 3 & Medium \\
\hline R24 & Kegagalan hardware & 2 & 3 & Medium \\
\hline R26 & Proses maintenance tidak terjadwal & 2 & 3 & Medium \\
\hline R02 & Gempa Bumi & 2 & 4 & Medium \\
\hline R11 & Server down & 2 & 4 & Medium \\
\hline R16 & Overload & 2 & 4 & Medium \\
\hline R04 & Kebakaran & 1 & 5 & Medium \\
\hline R13 & Overheat & 2 & 1 & Low \\
\hline R15 & Overcapacity & 2 & 1 & Low \\
\hline R08 & Penyalahgunaan hak akses & 1 & 2 & Low \\
\hline R09 & Kurangnya SDM & 2 & Low \\
\hline R12 & Backup Failure & 2 & Low \\
\hline R22 & Memori penuh & 3 & Low \\
\hline R01 & Banjir & Low \\
\hline R10 & Cybercrime \& Vandalisme & 3 & Low \\
\hline R25 & Serangan virus & 1 & Low \\
\hline
\end{tabular}

Dari tabel 6 telah ditemukan 4 kemungkinan risiko dengan tingkatan high yaitu: R07, R17, R18 dan R21. kemudian 13 kemungkinan risiko dengan tingkatan medium yaitu: R06, R14, R05, R19, R23, R03, R20, R24, R26, R02, R11, R16, R04. Dan yang terakhir terdapat 9 kemungkinan risiko dengan tingkatan low yaitu: R13, R15, R08, R09, R12, R22, R01, R10, R25. Hasil dari 26 kemungkinan risiko tersebut selanjutkan akan diberikan perlakuan risiko yang sesuai dengan kendala yang ada.

\subsection{Perlakuan risiko (Risk Threatment)}

Setelah melakukan proses pengelompokan analisis risiko langkah berikutnya yaitu memberikan usulan pada tahap perlakuan risiko. Pada tahap ini akan dilakukan pemberian usulan tindakan risiko yang tepat terhadap kemungkinan risiko yang ada pada perusahaan yang 
dikelompokkan berdasarkan tingkatan risiko pada tabel 7. Usulan perlakuan risiko bertujuan agar perusahaan mampu meminimalisir kemungkinan risiko yang munul dan dapat mengganggu bagi aplikasi CATTER pada PDAM Kota Salatiga dengan menggunakan acuan yang dapat dilihat pada tabel usulan perlakuan risiko.

Tabel 7. Usulan Perlakuan Risiko

\begin{tabular}{|c|c|c|c|}
\hline Id & $\begin{array}{l}\text { Kemungkinan } \\
\text { Risiko }\end{array}$ & $\begin{array}{l}\text { Risk } \\
\text { Level }\end{array}$ & Tindakan Risiko \\
\hline R07 & $\begin{array}{l}\text { Data dan Informasi } \\
\text { tidak sesuai }\end{array}$ & Iigh & $\begin{array}{l}\text { Melakukan pengecekan terhadap data dan inforr } \\
\text { secara berskala dan menyeluruh. }\end{array}$ \\
\hline R17 & $\begin{array}{l}\text { Web service mati } \\
\text { secara tiba-tiba }\end{array}$ & High & $\begin{array}{l}\text { Melakukan pengecekan server dan melakukan } \\
\text { troubleshooting pada saat web service mati, } \\
\text { maintenance dilakukan dengan tepat waktu. }\end{array}$ \\
\hline $\mathrm{R} 18$ & $\begin{array}{l}\text { Koneksi jaringan } \\
\text { terputus }\end{array}$ & High & $\begin{array}{l}\text { Mengganti ISP (Internet Service Proider) dengan yang } \\
\text { baru, dan lapor ke bagian jaringan agar jaringan } \\
\text { segera diperbaiki. }\end{array}$ \\
\hline $\mathrm{R} 21$ & $\begin{array}{l}\text { Dokumentasi data } \\
\text { tidak lengkap }\end{array}$ & High & $\begin{array}{l}\text { Mewajibkan petugas untuk selalu melakukan } \\
\text { pengecekan terhadap dokumentasi pada setiap objek. }\end{array}$ \\
\hline R06 & uman Error & Medium & SDM. \\
\hline $\mathrm{R} 14$ & Data corrupt & Medium & Melakukan backup data secara berskala. \\
\hline R05 & Listrik Padam & Medium & $\begin{array}{l}\text { Merencanakan backup plan sumber listrik seperti } \\
\text { menyediakan generator set listrik, kemudian } \\
\text { menyiapkan Uninterruptible Power Supply (UPS) } \\
\text { yang sesuai dengan kebutuan daya listrik pada } \\
\text { perusahaan. }\end{array}$ \\
\hline R19 & $\begin{array}{l}\text { Koneksi jaringan } \\
\text { tidak stabil }\end{array}$ & Medium & $\begin{array}{l}\text { engganti ISP (Internet Service Proider) dengan yang } \\
\text { ru. }\end{array}$ \\
\hline $\mathrm{R} 23$ & $\begin{array}{l}\text { Kegagalan } \\
\text { software }\end{array}$ & Medium & $\begin{array}{l}\text { Melakukan pengecekan terhadap driver, IRQ, atau } \\
\text { resource lainya pada PC, jika diperlukan melakukan } \\
\text { install ulang pada OS. }\end{array}$ \\
\hline $\mathrm{R} 03$ & Petir & Medium & g alat penangkal petir. \\
\hline $\mathrm{R} 20$ & $\begin{array}{l}\text { Penyelasaian data } \\
\text { tidak tepat waktu }\end{array}$ & Medium & Memberikan deadline yang ketat pada setiap pegawai. \\
\hline $\mathrm{R} 24$ & $\begin{array}{l}\text { Kegagalan } \\
\text { hardware }\end{array}$ & Medium & $\begin{array}{l}\text { Memberikan asuransi dan perawatan yang sesuai } \\
\text { terhadap asset-aset hardware yang ada pada } \\
\text { perusahaan, melakukan maintenance teradap asset } \\
\text { hardware yang dilakukan secara berkala. }\end{array}$ \\
\hline $\mathrm{R} 26$ & $\begin{array}{l}\text { ntenance } \\
\text { lwal }\end{array}$ & Medium & $\begin{array}{l}\text { Melakukan penjadwalan maintenance rutin setiap } \\
\text { minggu. }\end{array}$ \\
\hline $\mathrm{R} 02$ & Gempa Bumi & Medium & $\begin{array}{l}\text { Menyediakan tempat yang aman untuk perangkat- } \\
\text { perangkat yang ada. }\end{array}$ \\
\hline R11 & Server down & Medium & $\begin{array}{l}\text { Melakukan pengecekan berskala pada database dan } \\
\text { server pada aplikasi catat meter. }\end{array}$ \\
\hline
\end{tabular}




\begin{tabular}{|c|c|c|c|}
\hline $\mathrm{R} 16$ & Overload & Medium & $\begin{array}{l}\text { Melakukan refresh penggunaan } \mathrm{db} \text { log, temp, dan } \\
\text { RAM. Serta melakukan pengecekan terhadap database } \\
\text { perusahaan. }\end{array}$ \\
\hline R04 & Kebakaran & Medium & Menyiapkan alat pemadam kebakaran. \\
\hline $\mathrm{R} 13$ & Overheat & Low & $\begin{array}{l}\text { Menyediakan ruang yang memiliki pendingin ruangan } \\
\text { seperti AC serta menambah fan pada semua hardware } \\
\text { yang sesuai dengan kebutuhan perusahaan. }\end{array}$ \\
\hline $\mathrm{R} 15$ & Overcapacity & Low & $\begin{array}{l}\text { Memperhatikan kapasitas dalam proses penyimpanan } \\
\text { datanya dengan menambah kapasitas memori yang } \\
\text { lebih besar agar daya tampungnya juga lebih besar. } \\
\text { Melakukan cek memori secara berkala agar tidak } \\
\text { mengalami overcapacity. }\end{array}$ \\
\hline R08 & $\begin{array}{l}\text { Penyalahgunaan } \\
\text { hak akses }\end{array}$ & Low & Memberikan batasan akses pada setiap user. \\
\hline R09 & Kurangnya SDM & Low & $\begin{array}{l}\text { Membuka lowongan dan melakukan seleksi ketat } \\
\text { untuk SDM yang berkualitas. }\end{array}$ \\
\hline $\mathrm{R} 12$ & Backup Failure & Low & $\begin{array}{l}\text { Memperhatikan penggunaan memori yang dibutukan } \\
\text { oleh database perusahaan. Membuat maintenance plan } \\
\text { yang tepat. Serta membuat SOP dan melakukan } \\
\text { backup data secara berkala. }\end{array}$ \\
\hline $\mathrm{R} 22$ & Memori penuh & Low & $\begin{array}{l}\text { Menambah kapasitas memori yang lebih besar agar } \\
\text { daya tampungnya lebih optimal. Melakukan cek } \\
\text { memori secara berkala. Memperhatikan penggunaan } \\
\text { memori agar sesuai dengan kebutuhan database. }\end{array}$ \\
\hline R01 & Banjir & Low & $\begin{array}{l}\text { Menyiapkan tempat untuk server utama di daera yang } \\
\text { aman dari banjir, meletakkan dan menyimpan asset } \\
\text { perusahaan di tempat yang aman dari banjir. }\end{array}$ \\
\hline $\mathrm{R} 10$ & $\begin{array}{l}\text { Cybercrime } \\
\text { Vandalisme }\end{array}$ & Low & $\begin{array}{l}\text { Mengganti password dan melakukan pemerikasaan } \\
\text { data server secara berkala. Memasang dan memantau } \\
\text { CCTV di setiap titik gedung perusahaan agar lebih } \\
\text { aman. }\end{array}$ \\
\hline $\mathrm{R} 25$ & Serangan virus & Low & $\begin{array}{l}\text { Melakukan scanning antivirus terhadap portable } \\
\text { device, dan selalu mengaktifkan firewall dan internet } \\
\text { security. }\end{array}$ \\
\hline
\end{tabular}

\section{KESIMPULAN}

Berdasarkan penelitian analisis risiko teknologi informasi pada aplikasi Catat Meter PDAM Kota Salatiga dengan menggunakan metode ISO 31000 yang terdiri dari beberapa tahapan yang menjadi simpulan hasil analisis risiko. Hasil analisis yang didapatkan berupa hasil tingkatan risiko yang memiliki likelihood dan impact terhadap asset pada aplikasi Catat Meter. Dari beberapa faktor yang ada diantaranya yaitu faktor alam atau lingkungan, faktor manusia, serta faktor system dan infrastruktur yang berpotensi menggaggu kinerja pada aplikasi Catat Meter terdapat 26 kemungkinan risiko didalamnya. Dari 26 kemuningkinan risiko terseut terdapat 4 kemungkinan risiko memiliki level of risk yang termasuk dalam tingkatan high yaitu 
data dan informasi tidak sesuai, web service mati secara tiba-tiba, koneksi jaringan terputus, dan dokumentasi data tidak lengkap. Kemudian terdapat 13 kemungkinan risiko memiliki level of risk yang termasuk dalam tingkatan medium yaitu human error, data corrupt, listrik padam, koneksi jaringan tidak stabil, kegagalan software, petir, penyelesaian data tidak tepat waktu, kegagalan hardware, proses maintenance tidak terjadwal, gempa bumi, server down, overload, kebakaran. Terdapat 9 kemungkinan risiko yang termasuk level of risk dalam tingkatan low diantaranya overhead, overcapacity, penyalagunaan hak akses, kurangnya SDM, backup failure, memori penuh, banjir, cybercrime \& validasme, dan serangan virus.

Sebenarnya proses penanggulangan risiko pada asset aplikasi Catat Meter yang dipengaruhi oleh beberapa faktor yang dapat mengganggu kinerja aplikasi Catat Meter sudah dilaksanakan oleh PDAM Kota Salatiga, namun terdapat beberapa kendala dalam proses penanggulangan tersebut yaitu proses maintenance pada asset yang dimiliki oleh aplikasi Catat Meter tidak dilakukan secara berkala dan belum dilakukan secara optimal. Sehingga dengan adanya penelitian ini dapat dijadikan tolak ukur oleh perusahaan dan dijadikan pedoman untuk membantu dalam mengukur tingkat kemungkinan risiko yang terjadi pada aplikasi Catat Meter dan meminimalisir risiko baik yang terjadi saat ini maupun dimasa yang akan datang agar tidak menghambat kinerja pada PDAM Kota Salatiga.

\section{SARAN}

Untuk meminimalisir kemungkinan rsiko yang muncul sebaiknya PDAM Kota Salatiga memberikan maintenance maupun pengarahan yang bersifat monitoring terhadap pegawai pada bagian catat meter. Rekomendasi yang tepat dalam proses penanggulangan risiko yang ada dengan menerapkan risk Reduction yang bertujuan untuk mengurangi kemungkinan dan dampak yang yang terjadi pada kemungkinan risiko yang disebabkan oleh faktor manusia. Hal yang dilakukan yaitu dengan melakukan pendidikan dan pelatihan kepada pegawai catat meter agar dalam proses penginputan data tidak mengalami kesalahan yang menjadikan risiko paling tinggi sehingga informasi yang didapatkan sesuai dengan realita di lapangan.

\section{UCAPAN TERIMA KASIH}

Ucapan terima kasih disampaikan pertama-tama kepada Tuhan Yang Maha Esa yang senantiasa memberikan rahmat serta hidayanya sehingga penulis dapat menyelasaikan karya ilmiah ini. Penulis mengucapkan terima kasih kepada kedua orang tua, keluarga, teman-teman, serta pihak narasumber dari PDAM Kota Salatiga yang telah besedia membantu dalam proses penyusunan karya ilmiah ini.

\section{DAFTAR PUSTAKA}

[1] S. Wiyono and A. R. Tanaamah, 2017, "Analisis Kinerja SI/TI pada PDAM Kota Salatiga Menggunakan Kerangka IT Balanced Scorecard," J. Buana Inform., Vol. 8, No. 4, pp. 181-192, doi: 10.24002/jbi.v8i4.1442.

[2] H. T. I. Driantami, Suprapto, and A. R. Perdanakusuma, 2018 "Analisis Risiko Teknologi Informasi Menggunakan ISO 31000 (Studi Kasus: Sistem Penjualan PT. Matahari Department Store Cabang Malang Town Square)," J. Pengemb. Teknol. Inf. dan Ilmu 
Komput., Vol. 2, No. 11, pp. 4991-4998.

[3] F. A. Anshori and A. R. Perdanakusuma, 2019, "Perencanaan Keamanan Informasi Berdasarkan Analisis Risiko Teknologi Informasi Menggunakan Metode OCTAVE dan ISO 27001 (Studi Kasus Bidang IT Kepolisian Daerah Banten)," J. Pengemb. Teknol. Inf. dan Ilmu Komput., Vol. 3, No. 2, pp. 1701-1707, [Online]. Available: http://jptiik.ub.ac.id.

[4] D. E. Adi and N. Susanto, 2017. "Analisis Manajemen Risiko Aktivitas Pengadaan pada Percetakan Surat Kabar,” J. Metris, Vol. 18, pp. 113-118,

[5] M. Miftakhatun, 2020, "Analisis Manajemen Risiko Teknologi Informasi pada Website Ecofo Menggunakan ISO 31000,” J. Comput. Sci. Eng., Vol. 1, No. 2, pp. 128-146, doi: 10.36596/jcse.v1i2.76.

[6] A. Rahmawati and A. F. Wijaya, 2019 "Analisis Risiko Teknologi Informasi Menggunakan ISO 31000 pada Aplikasi ITOP,” J. SITECH Sist. Inf. dan Teknol., Vol. 2, No. 1, pp. 13-20, , doi: 10.24176/sitech.v2i1.3122.

[7] R. M. Candra, Y. N. Sari, I. Iskandar, and F. Yanto, 2019 "Sistem Manajamen Risiko Keamanan Aset Teknologi Informasi Menggunakan ISO 31000 : 2018,” Vol. 5, No. 1, pp. $19-28$.

[8] Y. Erlika, M. I. Herdiansyah, and A. H. Mirza, 2020, "Analisis IT Risk Management di Universitas Bina Darma Menggunakan ISO31000,” J. Ilm. Inform. Glob., Vol. 11, No. 1, doi: 10.36982/jig.v11i1.1073.

[9] U. Nugraha and R. Istambul, 2019. "Implementation of ISO 31000 for Information Technology Risk Management in The Government Environment," Int. J. Innov. Creat. Chang., Vol. 6, No. 5, pp. 219-231,

[10] F. M. Hutabarat et al., "Jurnal Bina Komputer Analisis Resiko Teknologi Informasi Aplikasi VCare PT. Visionet Data Internasional Menggunakan ISO 31000,” Vol. 2, No. 1, pp. 52-65.

[11] G. W. Lantang, A. D. Cahyono, and M. N. N. Sitokdana, 2019, "Analisis Risiko Teknologi Informasi Pada Aplikasi Sap Di Pt Serasi Autoraya Menggunakan Iso 31000," Sebatik, Vol. 23, No. 1, pp. 36-43, [Online]. Available: https://jurnal.wicida.ac.id/index.php/sebatik/article/view/441.

[12] M. Monica, didik Kurniawan, and R. Prabowo, 2020, "Analisis Manajemen Risiko Sistem Informasi Pengelolaaan Data English Proficiency Test (EPT) dan Portal Informasi di UPT Bahasa Universitas Lampung Menggunakan Metode ISO 31000,” J. Komputasi, Vol. 8, No. 1, pp. 83-90, doi: 10.23960/komputasi.v8i1.2351.

[13] F. L. Nice and R. V. Imbar, 2017. "Analisis Risiko Teknologi Informasi pada Lembaga Penerbangan dan Antariksa Nasional (LAPAN) pada Website SWIFTS Menggunakan ISO 31000,” J. Inform. dan Sist. Inf., Vol. 2, No. 2, pp. 1-11, 